\title{
Oil content and fatty acid composition of soybean (Glysine max L.) genotypes evaluated under rainfed conditions of Kashmir Himalayas in India
}

\author{
Sheikh Mohammad Sultan ${ }^{1^{*}}$, Nilamani Dikshit ${ }^{2}$ and Umesh J. Vaidya ${ }^{3}$ \\ ${ }^{1}$ National Bureau of Plant Genetic Resources (NBPGR) Regional Station, Srinagar-190007 (Jammu \& Kashmir), INDIA \\ ${ }^{2}$ National Bureau of Plant Genetic Resources (NBPGR) Regional Station, Akola- 444104 (Maharashtra), INDIA \\ ${ }^{3}$ Nuclear Agriculture and Biotechnology Division (NABTD), Bhaba Atomic Research Center, Trombay, Mumbai- \\ 400085 (Maharashtra), INDIA \\ *Corresponding author. E-mail: sheikhmsultan@gmail.com
}

Received: May 14, 2015; Revised received: October 10, 2015; Accepted: November 8, 2015

\begin{abstract}
Soybean (Glycine max), a multipurpose crop with much appreciated nutritional and functional properties, has generated a lot of interest during last few decades for improving its cultivation and characteristics. Besides having a great potential of energy-protein malnutrition eradication, it can contribute greatly to edible oil pool in the region. This study investigates some agro-morphological characters, besides seed oil content and fatty acid composition of two local soybean genotypes labeled as S/D-18 and S/D-22 grown under rainfed conditions of Kashmir Himalayas in India. The genotype S/D-22 matured earlier than that of S/D-18. Seed yield/plant of $18.5 \mathrm{~g}$ (S/D-18) and $20.1 \mathrm{~g}$ (S/D-22) was recorded in these genotypes with 100 -seed weight of $14.3 \mathrm{~g}$ and $14.7 \mathrm{~g}$ respectively. Seeds of genotype S/D-18 yielded an oil content of $19.54 \%$ while in genotype S/D-22 oil content of $19.74 \%$ was recorded. Fatty acids of myristic, palmitic, stearic, oleic, linoleic and linoleinic were detected and quantified in the oil extracted from the seeds of these genotypes. Saturated fatty acids constituted $11.88 \%(S / D-18)$ and $11.42 \%(S / D-22)$ while unsaturated fatty acids constituted $88.12 \%(S / D-18)$ and $88.58 \%(S / D-22)$ of the oil. The study has thus, revealed that under dry land conditions, although soybean seed yield/plant is lesser, percentage oil content and fatty acid composition essentially remained unaltered and that significant differences can occur in individual fatty acid contents between genotypes.
\end{abstract}

Keywords: Evaluation, Fatty acids, Gas chromatography, Oil content, Soybean genotypes

\section{INTRODUCTION}

The soybean [Glycine $\max (\mathrm{L}$.$) Merrill, family Legumi-$ nosae] classified as an oilseed rather than a pulse by UN Food and Agricultural Organization (FAO) is of worldwide interest (Cheng et al., 2008; Lee et al., 2008). It is one of the most important agricultural crops for oil and protein and has a natural capacity to fix nitrogen from the atmosphere (Singh and Hymowitz, 1999). It has been the dominant oilseed since the 1960 s besides, containing $40 \%$ protein unlike most other beans that contain only about $20 \%$ protein (Greenberg and Hartung, 1998). Oil content in dry soybean seeds on an average is $19 \%$ and can vary from $6.5 \%$ to $28.7 \%$ depending on the plant genetic background and growth conditions (Weselake et al., 2009). Soybean is a multipurpose crop used as human food, livestock feed, for industrial purposes, and more recently, as a source of bio-energy (Myaka et al., 2005). The domestication of Glycine max from the wild species (Glycine soja Sieb. and Zucc.) occurred in China but there is no consensus about the location within China (Carter et al., 2004). Glycine max differs from $G$. soja with smaller pods and seeds, stems that are viny and twining, and nearly complete shattering at plant maturity. The cultivated landraces were initially introduced into Korea and later into Japan some 2000 years ago (Kihara, 1969) and then distributed throughout Asia and more recently extended to Europe and America (Tavaux-Pirra et al., 2009). Soybeans thus have been grown as a food crop for thousands of years in China and other countries of East and South East Asia and constitute to this day, an important component of the traditional popular diet in these regions. Despite its economic importance as crop for feed, oil and soy food products, the genetic base of soybean cultivars is extremely narrow. The indigenous cultivars and landraces in East Asia are on the verge of extinction because farmers are now growing high yielding soybean cultivars (Singh and Hymowitz, 1999). Soybean is grown in around 50 countries of the world (Boerma and Specht, 2004) and its production has reached 249 million metric tons (mmt) in 2014. Brazil (90.0 mmt), United States $(89.5 \mathrm{mmt})$, Argentina $(52.6 \mathrm{mmt})$, China $(15.0 \mathrm{mmt})$ and India $(9.8 \mathrm{mmt})$ are the leading producers (FAO, 2014). Despite the relatively low oil content of the seed (about $20 \%$ on 
moisture-free basis), soybeans are the largest single source of edible oil and account for roughly $50 \%$ of the total oilseed production of the world.

In India it is believed that soybean came centuries ago probably either from China through the Himalayan mountains or from Indonesia via Burma (Myanmar) (Singh, 2006). Until 1970 its cultivation was negligible in the country however, during last 45 years especially since 1990 there has been a tremendous increase in the area under its cultivation besides production supplementing about $25 \%$ of edible oil produced in India, thus playing a very important role in resolving edible oil deficit situation (Sharma et al., 2014). The production of soybean in India (4\% of global) at present is restricted mainly to states of Madhya Pradesh, Uttar Pradesh, Maharashtra and Gujarat. It is also grown on small scale acreage in Himachal Pradesh, Punjab and Delhi (Singh, 2006). In 1940s and 50s the NorthWestern Indian Himalayan state of Jammu and Kashmir was leading in production of soybeans; 502 tons on 1,757 acres (Shurtleff and Aoyagi, 2012). Presently however as compared to other Indian states, soybean cultivation and production in Jammu and Kashmir is negligible. It is raised on a small scale for domestic use either pure or in mixture with maize. The tradition of sowing soybean on paddy field bunds is still followed at some places in the state although this practice was much more common few decades back and is supposed to give some protection to paddy field bunds besides yielding few kilograms of seed for household use. Roasted soybean seeds frequently sold by street vendors across the state have been a popular snack of local

Table 1. Average monthly temperature and rainfall recorded during the soybean growing season in Srinagar, Jammu and Kashmir (India).

\begin{tabular}{lccc}
\hline \multirow{2}{*}{ Month } & \multicolumn{2}{c}{ Temperature $\left({ }^{\mathbf{0}} \mathbf{C}\right)$} & \multirow{2}{\text{Rainfall}}{} \\
\cline { 2 - 3 } & Minimum & Maximum & $(\mathbf{m m})$ \\
\hline April & 8 & 19 & 99 \\
May & 11 & 24 & 53 \\
June & 15 & 29 & 17 \\
July & 19 & 30 & 47 \\
August & 17 & 29 & 71 \\
September & 13 & 25 & 120 \\
October & 9 & 22 & 39 \\
\hline
\end{tabular}

Table 2. Agro-morphological traits of 2 soybean (Glysine max) genotypes evaluated under rainfed conditions of Kashmir Himalayas.

\begin{tabular}{lcc}
\hline \multirow{2}{*}{$\begin{array}{l}\text { Agro-morphological } \\
\text { trait }\end{array}$} & \multicolumn{2}{c}{ Genotype } \\
\cline { 2 - 3 } & S/D-18 & S/D-22 \\
\hline Plant height (cms) & $79.5 \pm 4.6$ & $80.5 \pm 5.0$ \\
Days to maturity & $151.0 \pm 2.6^{\mathrm{b}}$ & $140.0 \pm 1.5$ \\
Number of pods/plant & $102.0 \pm 8.7$ & $113.3 \pm 19.6^{\mathrm{b}}$ \\
Number of seeds/pod & $1.4 \pm 0.4$ & $1.5 \pm 0.6$ \\
Seed yield/plant $(\mathrm{g})$ & $18.5 \pm 3.3$ & $20.1 \pm 3.9^{\mathrm{b}}$ \\
100-seed weight $(\mathrm{g})$ & $14.3 \pm 0.7$ & $14.7 \pm 0.5$ \\
\hline
\end{tabular}

Values are mean $\pm \mathrm{SD} ;{ }^{\mathrm{b}}$ Means are significantly higher at $5 \%$ level of confidence people especially during harsh winters. The indigenous black soybeans grown mostly in the Himalayan range especially in Kumau and Garwal region are also cultivated in some parts of Jammu and Kashmir and often used as livestock feed during winters. Considering the potential of soybean towards contributing to edible oil pool and energy-protein malnutrition eradication together with current prices and global production trends, there is much scope and therefore a strong need for promotion of sustainable soybean production in the state of Jammu and Kashmir. Data on oil content and fatty acid composition of local soybean germplasm are limited. Such studies are necessary for proper utilization of the crop. The main aim of present study was therefore, to determine oil content and investigate fatty acid composition in local soybean genotypes evaluated under dry land conditions of Kashmir Himalayas.

\section{MATERIALS AND METHODS}

Plant material and growing conditions: The seeds of the two genotypes of soybean [Glycine max (L.) Merrill] labeled as S/D-18 and S/D-22 were collected in 2013 from hills in Doda district of Jammu province of North-Western Indian Himalayan state of Jammu and Kashmir $\left(33^{\circ} 17^{\prime}-37^{\circ} 20^{\prime} \mathrm{N}\right.$ latitude, $73^{\circ} 25^{\prime}-80^{\circ}$ $30^{\prime} \mathrm{E}$ longitude). The experiment was conducted during summer (Kharif) season in 2014 under rainfed conditions at the Experimental Farm of National Bureau of Plant Genetic Resources, Regional Station Srinagar, Jammu and Kashmir (33 59' N latitude, 74 ${ }^{\circ} 7^{\prime}$ E longitude, $1639 \mathrm{~m}$ above sea level). The experimental site is located in dryland area falling within temperate climatic zone. The seeds were sown in rows in the beds which were three (03) meters wide; the individual rows were 40 centimeter apart. Ten rows with a minimum of seven plants/row were maintained for each genotype. The average monthly temperatures and rainfall during the study period are shown in Table 1 . Physical and chemical properties of the soil were determined before the start of experiment. The soil was having clay, silt and sand in the proportion of

Table 3. Oil content and fatty acid composition of 2 soybean (Glysine max) genotypes evaluated under rainfed conditions of Kashmir Himalayas.

\begin{tabular}{lll}
\hline & \multicolumn{2}{c}{ Genotype } \\
\cline { 2 - 3 } & S/D-18 & S/D-22 \\
\hline Total oil & $19.54 \pm 0.017$ & $19.74 \pm 0.104$ \\
content (\%) & & \\
\hline Fatty acid & & \\
content (\%) & & \\
Myristic acid & $0.065 \pm 0.0004^{\mathrm{b}}$ & $0.058 \pm 0.0005$ \\
Palmitic acid & $9.79 \pm 0.00021$ & $0.20 \pm 0.0007$ \\
Stearic acid & $2.02 \pm 0.0035^{\mathrm{b}}$ & $1.15 \pm 0.0052$ \\
Oleic acid & $20.09 \pm 0.0035$ & $20.88 \pm 0.0017$ \\
Linoleic acid & $56.79 \pm 0.0017$ & $57.91 \pm 0.0035^{\mathrm{b}}$ \\
Linoleinic acid & $11.24 \pm 0.0052^{\mathrm{b}}$ & $9.79 \pm 0.0104$ \\
\hline Values are mean of three replicates & $\pm \mathrm{SD} ;{ }^{\mathrm{b}}$ Means are \\
significantly higher at $5 \%$ level of confidence
\end{tabular}




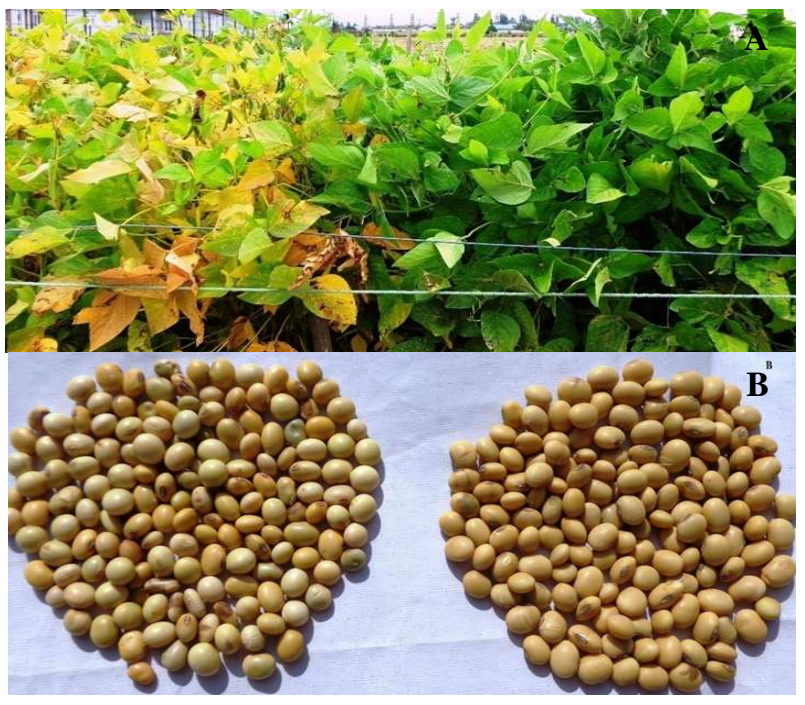

Fig. 1. Soybean (Glysine max) genotypes $S / D-22$ and $S / D-18$ evaluated in the present study.

33.4:60:6.6 with organic carbon content of $1.02 \%$, electrical conductivity of $0.133 \mathrm{mhos} / \mathrm{cm}$ and $\mathrm{pH}$ of 6.23. Available nitrogen, phosphorus and potassium content in the soil was $322.54 \mathrm{ppm}, 17.57 \mathrm{ppm}$ and 451.63 ppm respectively.

Agro-morphological characterization: Ten plants of each genotype were randomly sampled for recording plant height $(\mathrm{cm})$, number of pods/plant and seed yield/plant (g). 100-seed weight was determined in three independent samples from pooled grain yield. Plants growing on the peripheries of the experimental plot were not considered for sampling.

Determination of oil content and fatty acid profile: Once harvested, seeds were cleaned and dried to approximately $7 \%$ moisture. Seed oil content in three samples from each genotype was determined by a wide line nuclear magnetic resonance (NMR) method according to Robertson and Morrison(1979).

The concentration of fatty acids was measured as their corresponding methyl esters. The preparation of methyl esters of fatty acids (FAMEs) was carried out according to the International Standard ISO 5509:2000 - boron trifluoride (BF3) method (EN ISO 5509:2000). 5-10 seeds were crushed with the help of mortor and pestle and 1.5-2.0 $\mathrm{g}$ of this crushed material was taken in test tubes. After adding $3 \mathrm{ml}$ petroleum ether the tubes were covered with teflon and kept overnight. 2 $\mathrm{ml} 0.5 \mathrm{~N} \mathrm{NaOH}$ prepared in methanol were added and mixed gently and the tubes were placed in hot water bath at $90-97^{\circ} \mathrm{C}$ for $5 \mathrm{~min}$. Afterwards, $2 \mathrm{ml}$ boron trifluoride $\left(\mathrm{BF}_{3}\right)$ was added and contents were stirred and tubes again placed in water bath at $97^{\circ} \mathrm{C}$ for $5 \mathrm{~min}$. Then $3 \mathrm{ml}$ petroleum ether and $2 \mathrm{ml}$ deionized water were added followed by stirring. Two layers got separated as the tubes were left undisturbed for one hour at room temperature. From upper layer $1 \mathrm{ml}$ sample was taken in GC vials for analysis. Analysis was carried out using Gas Chromatograph (GC) Model-14B, Shi- madzu, Japan equipped with SP-2340 flexible fused silica capillary column $(60 \mathrm{~m} \times 0.25 \mathrm{~mm} \times 0.2 \mu \mathrm{m}$ film thickness) and a flame ionization detector. Nitrogen was used as a carrier gas with flow rate of $20 \mathrm{ml} / \mathrm{min}$, and the column oven was set to $185^{\circ} \mathrm{C}$, and the injector and detector were set to $200^{\circ} \mathrm{C}$. The relative percentage (area $\%$ ) of the fatty acids was determined using a reference mixture of methyl esters of fatty acids. The analyses were carried out in triplicate.

Statistical analysis: Student's $t$-test (Microsoft Excel) was used to assess the significance of differences between mean values. Differences were considered significant for $p$ values $<0.05$.

\section{RESULTS AND DISCUSSION}

The mean values of agro-morphological traits recorded during our present study are given in Table 2. While plant height is almost same in the two genotypes there is a significant difference in days to maturity; yellowing of leaves in genotype S/D-22 occurred earlier maturing 11 days earlier than that of S/D-18 (Fig. 1). Significantly higher number of pods/plant has also been recorded in genotype S/D-22 as compared to genotype S/D-18 with almost same number of seeds/ pod in both the genotypes. Compared to plant height there was a greater variation in number of pods among individual plants. Majority of the pods in both genotypes were having one or two rarely three seeds. Seeds in these genotypes are yellowish or light yellow in color and more or less spherical or oval shaped. In genotype S/D-22 comparatively higher seed yield/plant and 100-seed weight has been recorded than in genotype S/D-18.

The oil content and fatty acid composition of these soybean genotypes has been presented in Table 3 . Higher oil content of $19.74 \%$ has been recorded in genotype S/D-22 than in S/D-18(19.54\%). The fatty acids detected in the oil extracted from seeds of the two genotypes during present study are myristic, palmitic, stearic, oleic, linoleic and linoleinic (Fig. 2). In the oil obtained from seeds of genotype S/D-18, significantly higher contents of myrystic, stearic and linoleinic acids were recorded compared to S/D-22 whereas in latter genotype comparatively higher contents of palmitic, oleic and linoleic acids were recorded than in S/D-18, the difference was significant only in case of linoleic acid. Our study has thus revealed that saturated fatty acids constitute $11.88 \%$ (S/D-18) and $11.42 \%$ (S/D-22) while unsaturated fatty acids constitute $88.12 \%$ (S/D-18) and 88.58\% (S/D-22) of the oil. Soybeans grow well in almost all types of soil except sandy soils with very poor water retention, growing best in temperate climates. Rainfall, temperature and photoperiod during the growing season are determinant environmental factors affecting grain yield. Drought particularly in the reproductive growth stage (Oya et al., 2004) is the most important abiotic stress limiting soybean yield (Specht et al., 1999; Purcell and Specht, 

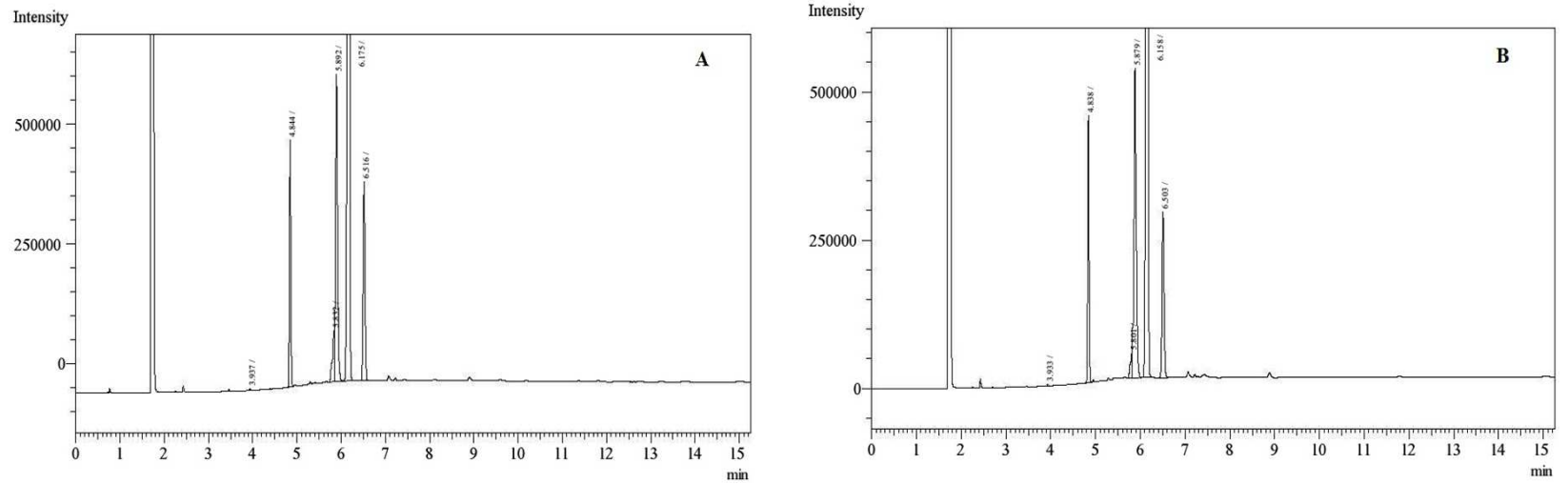

Fig. 2. Gas chromatograms showing separation of FAMEs in the oil extracted from seeds of two soybean (Glysine max) genotypes $S / D-18(A)$ and $S / D-22(B)$.

2004). Rainfall in the range of 500 to $700 \mathrm{~mm}$ is required for good yields. Adequate water supply is especially important during the period of pod and seed development. Grain yield is one of the most important selection criteria used by breeders. It is influenced by different yield components that include number of pods and seeds per plant as well as weight of 100 seeds (Rotzler et al., 2009). Seed weight of commercially grown soybeans are generally $10-20 \mathrm{~g} / 100$ seeds but can be larger than $30 \mathrm{~g} / 100$ seeds or smaller than 6 $\mathrm{g} / 100$ seeds (Lersten and Carlson, 2004). Lesser number of seeds/pod recorded during the course of present study compared to normal average of 2.5 seeds and consequently lower yield/plant can be attributed to stressful conditions mostly due to inadequate or untimely rainfall. Slow wilting and minimal yield reduction under drought are important traits in evaluating drought tolerance. Genetic improvement for drought tolerance therefore, is an effective method to reduce yield loss in soybean (Pathan et al., 2014). It is a proven fact that narrow row spacing is a risk management tool that helps to stabilize soybean yields in stressful environments, that is why row spacing in present experimentation was kept only $40 \mathrm{cms}$. Narrow rows have a yield advantage because they achieve canopy closure more quickly and intercept more light throughout the growing season besides preventing moisture loss from the soil. Being a short-day plant soybean flowers when the nights begin to lengthen. Soybean plants flower earlier when daylight period is short. That is why plants flowered during the months of June and July in the present study although seeds were sown in the last week of April.

Oil content can vary from $6.5 \%$ to $28.7 \%$ in dry soybean seeds depending on the plant genetic background and growth conditions (Weselake et al., 2009). Typically they contain about $20 \%$ oil on a dry weight basis (Wilson, 2004) and five fatty acids make up nearly the entire oil portion of soybean seed. Soybean oil averages $12 \%$ palmitic acid (16:0), $4 \%$ stearic acid (18:0), 23\% oleic acid (18:1), 53\% linoleic acid (18:2), and $8 \%$ linolenic acid (18:3). The 16:0 and 18:0 fractions are saturated fatty acids and constitute $15 \%$ of the soybean oil. The remainder of the oil (about $85 \%$ ) is made up of unsaturated fatty acids or 18:1, 18:2, and 18:3 (Lee et al., 2007). It has also been reported in a recent study that proportion of linoleic acid in soybean oil ranged from $49.0 \%$ to $53.5 \%$, oleic acid from $21.4 \%$ to $26.6 \%$ while palmitic acid was found to be in the range of $9.2 \%$ to $11.2 \%$ (Matthaus and. Ozcan, 2014). In yet another more recent study linoleic, linolenic and stearic acids were reported to constitute $50.20 \%, 7.75 \%$ and $3.69 \%$ of soybean oil respectively (Mohammadi, 2015). Our results therefore almost corroborate with the earlier reports. It is because of high percentage of polyunsaturated fatty acids (18:2 and 18:3) that soybeans are considered to be unstable (Neff and List, 1999). Fatty acid composition is a major determinant of oil quality in oilseeds and is therefore, an important consideration for breeding programs (Daun, 1998). Proper levels of unsaturated fatty acid moieties in vegetable oils have been recognized as good nutritional characteristics for health. One goal of breeding projects is the alteration of the fatty acid composition, for example, the reduction of the level of linoleic acid moiety. The ideal oil with the most end uses would have saturates (palmitic + stearic acids) reduced from 15 to $<7 \%$, oleic acid increased from 23 to $>55 \%$, and linolenic acid reduced from 8 to $<3 \%$ (Lee et al., 2007). Genetic sources are very important in improving soybean oil content although, genotype $\mathrm{x}$ environmental interactions which influence the oil concentration and fatty acid profile of soybean oil have been addressed in many studies. Moisture stress effects on yield, seed weight, oil and protein contents of seeds were evaluated in dry land and irrigated plots and 57$68 \%$ of the seed weight loss was attributed to changes in weight per seed of oil and protein (Rose, 1988). When compared to the irrigated treatments, the oil and protein percentages of the dry land seed varied. Studies have indicated that temperature plays an important role in the synthesis of oil and fatty acids. In general, higher temperature increases oil content in soybean seed (Wilson, 2004). Soybeans grown under high average temperatures have reduced linoleic acid and linolenic acid, and increased oleic acid content; however, 
contents of saturated fatty acids were changed little by environment (Wilson, 2004; Hou et al., 2006). Our study has revealed that under dry land conditions, although soybean seed yield/plant is lesser, \%age oil content and fatty acid composition essentially remained unaltered and that saturated fatty acid content in the two genotypes studied was around $11 \%$, value below the normal average of $15 \%$ suggesting the possibility of occurrence of soybean genotypes with such desired traits in the state of Jammu and Kashmir. Soybean, thus has a great potential to be exploited as an edible oilseed crop under dry land conditions throughout this Indian Himalayan state utilizing proper management practices. In absence of adequate rainfall, however, irrigation will always prove to be an essential factor for increased profit and security to the farmer.

\section{Conclusion}

Our study has revealed that under dry land conditions, although soybean seed yield/plant is lesser, percentage oil content and fatty acid composition essentially remained unaltered and that significant differences can occur in individual fatty acid contents between genotypes. Extensive survey in the entire state of Jammu and Kashmir may yield soybean genotypes with desired traits including abiotic and biotic stress tolerance. Characterization and evaluation of more soybean genotypes for such traits particularly under unfavorable environments where water stress is common and yields are low should accelerate breeding progress for promotion and exploitation of this crop as oil seed in the entire region.

\section{ACKNOWLEDGEMENTS}

The authors are thankful to Director, National Bureau of Plant Genetic Resources (NBPGR), Indian Council of Agricultural Research (ICAR), New Delhi and to Bhaba Atomic Research Center, Trombay, Maharashtra for facilities and help.

\section{REFERENCES}

Boerma, R. H. and Specht, J. E. (eds). (2004). Soybeans: improvement, production, and uses, $3^{\text {rd }}$ ed. Crop Science Society of America, Madison, WI, USA.

Carter, T. E., Nelson, R. L., Sneller, C. H. and Cuim, Z. (2004). Genetic diversity in soybean. In:R. H. Boerma and J. E. Specht (eds)Soybeans: Improvement, Production and Uses. $3^{\text {rd }}$ ed.Crop Science Society of America, Madison, WI, USA,pp.303-416.

Cheng, K. C., Beaulieu, J., Iquira, E., Belzile, F. J., Fortin, M. G. and Strömvik, M. V. (2008). Effect of transgenes on global gene expression in soybean is within natural range of variation of conventional cultivars. Journal of Agriculture and Food Chemistry, 56: 3057-067.

Daun, J. K.. (1998). Modified Fatty Acid Profiles in Canadian Oilseeds. Journal of Japanese Oil Chemists Society, 17:233-238.

EN ISO 5509 (2000): Animal and vegetable fats and oils Preparation of methyl esters of fatty acids. European Committee for Standardization, Brussels.
FAO (2014).UN Food \& Agriculture Organization. (http:// faostat.fao.org/site/ 339/default.aspx)

Greenberg, P. and Hartung, H. N. (1998). The whole soy cookbook: 175 delicious, nutritious, easy-toprepare recipes featuring tofu, tempeh, and various forms of nature's healthiest bean. Three Rivers Press, New York.

Hou, G., Ablett, G. R., Pauls, K. P. and Rajcan, I. (2006). Environmental effects on fatty acid levels in soybean oil. Journal of American Oil Chemists Society,83:759763.

Kihara, H.(1969). History of biology and other sciences in Japan in retrospect. Proceedings of XII International Congress of Genetics,3:49-70.

Lee Jeong-Dong, Bilyeu, K. D. and Shannon, J. G. (2007).Genetics and Breeding for Modified Fatty Acid Profile in Soybean Seed Oil.Journal of Crop Science and Biotechnology, 10(4): 201-210.

Lee, S. J., Kim, J. J., Moon, H. I., Ahn, J. K., Chun, S.C. and Jung, W. S (2008). Analysis of isoflavones and phenolic compounds in Korean soybean [Glycine $\max (\mathrm{L}$.) Merrill] seeds of different seed weights. Journal of Agriculture and Food Chemistry, 56: 2751- 2758.

Lersten, N. R. and Carlson J. B. (2004). Vegetative morphology. In:R. H. Boerma and J. E. Specht (eds) Soybeans: Improvement, Production and Uses. $3^{\text {rd }}$ ed. Crop Science Society of America, Madison, WI, USA, pp. 15-57.

Matthaus, B. and Ozcan, M. M. (2014). Fatty acid and tocopherol contents of several soybean oils. Natural Product Research, 28 (8): 589-592.

Mohammadi, K. (2015). Grain oil and fatty acids composition of soybean affected by nano-iron chelate, chemical fertilizers and farmyard manure. Archives of Agronomy and Soil Science, 61(11): 1593-1600.

Myaka, F. A., Kirenga, G. and Malema, B.(eds). (2005). Proceedings of the First National Soybean Stakeholders Workshop, 10 -11 November 2005, Morogoro,Tanzania.

Neff, W. E. and List, G. R. (1999). Oxidative stability of natural and randomized high-palmitic andhigh-stearic acid oils from genetically modified soybean varieties. Journal of American Oil Chemists Society,76:825-831.

Oya, T., Nepomuceno, A. L., Numaier, N., Farias, J. R. B.,Tobita, S. and Ito, S. (2004). Drought tolerance characteristics of Brazilian cultivars - evaluation and characterization of drought tolerance of various Brazilian soybean cultivars in the field. Plant Production Science, 7:129-137.

Pathan, S. M.,Lee, J-D,Sleper, D. A.,Fritschi, F. B., Sharp, R. E.,Carter Jr, T. E.,Nelson, R. L., King, C. A.,Schapaugh, W. T.,Ellersieck, M. R., Nguyen, H. T. and Shannon, J. G. (2014).Two Soybean Plant Introductions Display Slow Leaf Wilting and Reduced Yield Loss under Drought. Journal of Agronomy and Crop Science, 200: 231-236.

Purcell, L. C. and Specht, J. E. (2004). Physiological traits for ameliorating drought stress. In: R. H. Boerma and J. E. Specht (eds) Soybeans: Improvement, Production and Uses. $3^{\text {rd }}$ ed. Crop Science Society of America, Madison, WI, USA, pp. 520-569.

Robertson, J.A. and Morrison, W.H. (1979). Analysis of oil content of sunflower seed by wide - line NMR. Journal of American Oil Chemists Society, 56 (12): 961-964.

Rose, I. A. (1988). Effects of moisture stress on the oil and protein components of soybean seed. Australian Journal Agricultural Research,39:163-170.

Rotzler, D. P., Stamp, C-A., Betrix, E.,De Groote, J-C., Moullet, 
O. and Schori, A. (2009). Agronomic relevance of lanceolate leaf in soybean.Revue Suisse Agric., 41(3):153-159.

Sharma, A. N., Gupta, G. K., Verma, R. K., Sharma, O. P., Bhagat, S., Amaresan, N., Saini, M. R., Chattopadhyay, C., Sushil, S. N., Asre, R., Kapoor, K. S., Satyagopal, K. and Jeyakumar, P. (2014). Integrated Pest Management for Soybean. National Centre for Integrated Pest Management, IARI Campus, New Delhi; $\mathrm{p} 41$.

Shurtleff, W. and Aoyagi, A. (eds). (2012). History of Soy Sauce (160 CE to 2012). Soyinfo Center, Lafayette, CA, USA; p. 1101

Singh, B. B. (2006). Success of soybean in India: the early challenges and pioneer promoters. Asian Agri-History, 10(1): 4353.

Singh, R. J. and Hymowitz, T. (1999).Soybean genetic re- sources and crop improvement. Genome, 42:605-616.

Specht, J. E., Hume, D. J. and Kumudini, S. V. (1999). Soybean yield potential - a genetic and physiological perspective. Crop Science 39:1560-1570.

Tavaux-Pirra, M., Sartre, P.,Nelson, R.,Santoni, S.,Texier, N. and Roumet, P. (2009). Genetic diversity in a soybean collection. Crop Science, 49:895-902.

Weselake,R. J., Taylor, D. C., Rahman, M. H., Shah, S., Laroche, A., McVetty, P. B. E. and Harwood, J. L. (2009). Soybean yield potential - a genetic and physiological perspective. Crop Science, 39:1560-1570.

Wilson, R. F. (2004). Seed composition. In:R. H. Boerma and J. E. Specht (eds) Soybeans: Improvement, Production and Uses. $3^{\text {rd }}$ ed. Crop Science Society of America, Madison, WI, USA, pp. 621-677. 